\title{
OBSERVATIONS ON ALL BIRTHS $(23,970)$ IN BIRMINGHAM, 1947 \\ V. BIRTH WEIGHT RELATED TO ECONOMIC CIRCUMSTANCES OF PARENTS
}

BY

\author{
J. R. GIBSON and THOMAS MCKEOWN \\ From the Department of Social Medicine, University of Birmingham
}

This communication presents evidence on the association of the birth weight of children born in Birmingham during 1947 with the economic circumstances of their parents. This matter was considered by Baird (1945), who recorded differences in the proportion of infants born prematurely (as identified by weight) in nursing home, hospital, and specialist practice, and more recently by Douglas (1950), who noted slight but unimportant weight differences between children of professional and manual workers. Such comparisons clearly require some consideration of the effect of birth rank (as provided by Douglas, who dealt separately with first and later births), since weight is correlated with birth rank and the proportion of individuals in each birth rank is not constant in different economic groups.

As indices of the economic circumstances of the parents we have used a classification of Birmingham wards into three groups of which details, were provided by Record and McKeown (1949). Briefly, the city wards were classified using data from:

(1) The Housing Survey Report (1946), which gave for each ward the number of houses:
(a) back to back
(b) with bathroom
(c) with bath
(d) municipally-owned.

(2) The Birmingham City Statistical Office, which supplied the average rateable value for each ward.

(3) The Town Planning Department, which gave the surface area of each ward, from which were calculated (by wards):

(a) housing densities

(b) population densities, using the ward population given in the Report of the Medical Officer of Health, 1947.

This classification is essentially based on the standard of housing, which provides an index of the economic circumstances of residents. As might be 
TABLE I

Percentage Distributions of Births by Weight

\begin{tabular}{|c|c|c|c|c|c|c|c|}
\hline \multicolumn{2}{|c|}{ Birth Weight } & & & \multicolumn{2}{|c|}{ Ward Group } & & \\
\hline \multirow{2}{*}{ Pounds } & \multirow{2}{*}{ Half-pounds } & \multicolumn{2}{|c|}{ I } & \multicolumn{2}{|c|}{ II } & \multicolumn{2}{|c|}{ III } \\
\hline & & Number & Per cent. & Number & Per cent. & Number & Per cent. \\
\hline \multirow{2}{*}{1} & 2 & 1 & \multirow{2}{*}{$0 \cdot 10$} & 3 & \multirow{2}{*}{$0 \cdot 10$} & - & \multirow{2}{*}{$0 \cdot 13$} \\
\hline & 3 & 7 & & 7 & & 5 & \\
\hline \multirow{2}{*}{2} & 4 & 20 & \multirow{2}{*}{$0 \cdot 54$} & 21 & \multirow{2}{*}{$0 \cdot 45$} & 7 & \multirow{2}{*}{$0 \cdot 46$} \\
\hline & 5 & 25 & & 23 & & 11 & \\
\hline \multirow{2}{*}{3} & 6 & 28 & \multirow{2}{*}{$0 \cdot 67$} & 27 & \multirow{2}{*}{$0 \cdot 64$} & 13 & \multirow{2}{*}{0.94} \\
\hline & 7 & 28 & & 36 & & 24 & \\
\hline \multirow{2}{*}{4} & 8 & 73 & \multirow{2}{*}{$2 \cdot 04$} & 69 & \multirow{2}{*}{$1 \cdot 60$} & 24 & \multirow{2}{*}{$1 \cdot 52$} \\
\hline & 9 & 97 & & 87 & & 36 & \\
\hline \multirow{2}{*}{5} & 10 & $219 \cdot$ & \multirow{2}{*}{$7 \cdot 43$} & 248 & \multirow{2}{*}{$6 \cdot 60$} & 99 & \multirow{2}{*}{$6 \cdot 48$} \\
\hline & 11 & 399 & & 396 & & 157 & \\
\hline \multirow{2}{*}{6} & 12 & 852 & \multirow{2}{*}{$24 \cdot 37$} & 852 & 0 & 350 & 00 \\
\hline & 13 & 1,174 & & 1,291 & 21.80 & 555 & 22.91 \\
\hline 7 & 14 & 1,557 & 34.66 & 1,928 & 36,30 & 786 & 25.00 \\
\hline 1 & 15 & 1,324 & $34^{\circ} .00$ & 1,616 & 50.50 & 632 & צסם \\
\hline 8 & 16 & 1,199 & 2112 & 1,483 & 2201 & 602 & 2206 \\
\hline 0 & 17 & 557 & & 745 & & 333 & \\
\hline 9 & 18 & 410 & $7 \mathrm{~m}$ & 516 & 7.79 & 185 & 607 \\
\hline & 19 & 171 & & 204 & & 55 & 0.01 \\
\hline 10 & 20 & 122 & 1.80 & 146 & 1.01 & 59 & 1.77 \\
\hline 10 & 21 & 28 & & 41 & & 11 & \\
\hline & 22 & 12 & ?2 & 18 & 0.21 & 6 & $0-10$ \\
\hline 11 & 23 & 7 & 0.25 & 3 & 0.21 & 1 & 0.10 \\
\hline 12 & 24 & 2 & 0.07 & 1 & ב. & - & \\
\hline 12 & 25 & - & 0.02 & 1 & 002 & - & \\
\hline Over 12 & Over 25 & 1 & 0.01 & - & - & 1 & 0.03 \\
\hline Number 0 & Births & 8,313 & 100 & 9,762 & 100 & 3,952 & 100 \\
\hline Mean (lb.) & & $7 \cdot 38$ & - & $7 \cdot 46$ & - & $7 \cdot 43$ & - \\
\hline $\begin{array}{l}\text { Error of } \mathbf{N} \\
\text { Standard I }\end{array}$ & eviation & $\begin{array}{l}0.014 \\
1.28\end{array}$ & - & $\begin{array}{l}0.013 \\
1.25\end{array}$ & & $\begin{array}{l}0.019 \\
1.22\end{array}$ & - \\
\hline Standara & & $1 \cdot 28$ & & 125 & & $1 \cdot 22$ & - \\
\hline
\end{tabular}

Of 22,454 births (see Table III, Part II), 323 are excluded as previously indicated, and 104 others because the ward group was not known. 
expected, the ward groups so identified differ considerably in respect of live birth rates and infant mortality rates, as is indicated by data for 1946-47 which are as follows:

\begin{tabular}{|c|c|c|c|c|}
\hline Ward Group .. & I & II & III & All Wards \\
\hline $\begin{array}{l}\text { Birth Rate } \\
\text { Infant Mortality Rate }\end{array}$ & $\begin{array}{l}25 \cdot 7 \\
49 \cdot 2\end{array}$ & $\begin{array}{l}21 \cdot 0 \\
36 \cdot 5\end{array}$ & $\begin{array}{l}19 \cdot 7 \\
33 \cdot 1\end{array}$ & $\begin{array}{l}22 \cdot 4 \\
40 \cdot 4\end{array}$ \\
\hline
\end{tabular}

1947 births were assigned by place of domicile to one of the three groups; Table I gives percentage distributions by weight and the mean weights of births in each group. Of the original 22,527 births of known weight (97 per cent. of all single births in Birmingham during 1947), the following have been excluded:

(a) 73 in which the duration of gestation was less than 28 weeks

(b) 323 as indicated in Table III, Part II

(c) 104 for which ward group was not known.

Mean birth weight is slightly but significantly lower in Group I (in which housing standards are poorest) than in either of the other two groups; the difference in mean weights between Groups II and III is not significant. Weight distributions have also been compared by grouping births by weight in lb. (less than 4 ; 4-; $5 \frac{1}{2}$; 7-; 8 and over). The $\chi^{2}$ test gives values for $p$ as follows:

$$
\begin{array}{ll}
\text { I compared with II and III } & p<0.0001 \\
\text { II compared with III } & p \simeq 0.5 .
\end{array}
$$

We may now inquire whether these results are influenced by the differences in birth-rank constitution of births in the three ward groups exhibited in Table II, in which it is shown that the proportion of births at low birth ranks is highest in wards with better housing. Table III (overleaf) gives mean weights by birth rank, and shows the well-known increase in weight from the first to the third birth. Hence it might be expected that the difference in mean weights already noted in Table I

TABLE II

\begin{tabular}{|c|c|c|c|c|c|c|c|c|}
\hline \multirow{3}{*}{ Birth Rank } & \multicolumn{8}{|c|}{ Ward Group } \\
\hline & \multicolumn{2}{|c|}{ I } & \multicolumn{2}{|c|}{ II } & \multicolumn{2}{|c|}{ III } & \multicolumn{2}{|c|}{ Total } \\
\hline & Number & Per cent. & Number & Per cent. & Number & Per cent. & Number & Per cent. \\
\hline $\begin{array}{c}1 \\
2 \\
3 \\
4 \text { and over }\end{array}$ & $\begin{array}{l}2,746 \\
2,217 \\
1,213 \\
1,539\end{array}$ & $\begin{array}{l}35 \cdot 59 \\
28 \cdot 74 \\
15 \cdot 72 \\
19 \cdot 95\end{array}$ & $\begin{array}{l}3,560 \\
2,517 \\
1,209 \\
1,421\end{array}$ & $\begin{array}{l}40 \cdot 89 \\
28 \cdot 91 \\
13 \cdot 88 \\
16 \cdot 32\end{array}$ & $\begin{array}{r}1,615 \\
1,012 \\
509 \\
439\end{array}$ & $\begin{array}{l}45 \cdot 18 \\
28 \cdot 31 \\
14 \cdot 24 \\
12 \cdot 23\end{array}$ & $\begin{array}{l}7,921 \\
5,746 \\
2,931 \\
3,399\end{array}$ & $\begin{array}{l}39 \cdot 61 \\
28 \cdot 73 \\
14 \cdot 66 \\
17 \cdot 00\end{array}$ \\
\hline Total & 7,715 & 100 & 8,707 & 100 & 3,575 & 100 & 19,997 & 100 \\
\hline
\end{tabular}

Percentage Distribution of Births by Birth Rank

Ward group was unknown in 104 of 20,101 births of known birth rank (see Table V, Part II). 
TABLE III

Mean Birth Weight related to Birth Rank

\begin{tabular}{|c|c|c|c|c|}
\hline \multirow{2}{*}{ Birth Rank } & \multicolumn{4}{|c|}{ Ward Group } \\
\hline & $\mathbf{I}$ & II & III & Total \\
\hline 1 & $\begin{array}{c}7 \cdot 08 \\
\pm 0 \cdot 024\end{array}$ & $\begin{array}{c}7 \cdot 23 \\
\pm 0 \cdot 020\end{array}$ & $\begin{array}{c}7 \cdot 20 \\
\pm 0 \cdot 031\end{array}$ & $\begin{array}{c}7 \cdot 17 \\
\pm 0 \cdot 014\end{array}$ \\
\hline 2 & $\begin{array}{c}7 \cdot 41 \\
\pm 0 \cdot 027\end{array}$ & $\begin{array}{c}7 \cdot 50 \\
\pm 0 \cdot 025\end{array}$ & $\begin{array}{c}7 \cdot 52 \\
\pm 0 \cdot 038\end{array}$ & $\begin{array}{c}7 \cdot 46 \\
\pm 0 \cdot 017\end{array}$ \\
\hline 3 & $\begin{array}{c}7 \cdot 65 \\
\pm 0 \cdot 036\end{array}$ & $\begin{array}{c}7 \cdot 64 \\
\pm 0 \cdot 037\end{array}$ & $\begin{array}{c}7 \cdot 71 \\
\pm 0.053\end{array}$ & $\begin{array}{c}7 \cdot 65 \\
\pm 0 \cdot 026\end{array}$ \\
\hline 4 and over & $\begin{array}{c}7 \cdot 58 \\
\pm 0 \cdot 037\end{array}$ & $\begin{array}{c}7 \cdot 77 \\
\pm 0.037\end{array}$ & $\begin{array}{c}7 \cdot 61 \\
\pm 0 \cdot 070\end{array}$ & $\begin{array}{c}7.65 \\
\pm 0.026\end{array}$ \\
\hline $\begin{array}{l}\text { All Birth } \\
\text { Ranks }\end{array}$ & $\begin{array}{c}7 \cdot 38 \\
\pm 0 \cdot 014\end{array}$ & $\begin{array}{c}7 \cdot 46 \\
\pm 0.013\end{array}$ & $\begin{array}{c}7.43 \\
\pm 0.019\end{array}$ & $\begin{array}{c}7 \cdot 43 \\
\pm 0.008\end{array}$ \\
\hline
\end{tabular}

would be increased when births in the same rank are examined. The effect is mainly on first births, for which the means are:

\section{$7 \cdot 08$ in Group I \\ $7 \cdot 23$ in Group II \\ $7 \cdot 20$ in Group III}

The differences between Groups I and II are also substantial at birth ranks " 4 and over", but as numbers are smaller the standard errors are considerably greater.

Another question of interest in this context is the relation between duration of gestation and economic circumstances of parents. It is commonly stated that the incidence of " premature " birth is higher among poorer mothers,"but the index of maturity in such calculations has invariably been birth weight. Any substantial difference in the distributions by duration of gestation would, of course, influence weight at birth. Table IV gives the distribution of births by duration of gestation for each of the three ward groups. There are no significant differences in the means, which are:

$$
\begin{aligned}
& 280 \cdot 76 \text { in Group I } \\
& 280 \cdot 73 \text { in Group II } \\
& 280 \cdot 58 \text { in Group III }
\end{aligned}
$$

The data suggest that there are no conspicuous differences in the percentage distributions, and when the births are grouped by duration of gestation in weeks (35 and under; 36-; 39-; 42 and over) the $\chi^{2}$ test gives $p \simeq 0 \cdot 5$. Finally the association between mean weight, duration of gestation, and ward group is considered in Table $\mathrm{V}$. There is here no consistent relationship between weights of births in each group. 
TABLE IV

Percentage Distribution of Births by Duration of Gestation

\begin{tabular}{|c|c|c|c|c|c|c|c|}
\hline \multirow{3}{*}{$\begin{array}{l}\text { Duration of Gestation } \\
\text { (weeks) }\end{array}$} & & \multicolumn{6}{|c|}{ Ward Group } \\
\hline & & \multicolumn{2}{|c|}{ I } & \multicolumn{2}{|c|}{ II } & \multicolumn{2}{|c|}{ III } \\
\hline & & Number & Per cent. & Number & Per cent. & Number & Per cent \\
\hline $\begin{array}{l}28 \\
29 \\
30 \\
31 \\
32 \\
33 \\
34 \\
35 \\
36 \\
37 \\
38 \\
39 \\
40 \\
41 \\
42 \\
43 \\
44 \\
45 \\
46\end{array}$ & & $\begin{array}{r}5 \\
3 \\
7 \\
23 \\
14 \\
34 \\
44 \\
99 \\
191 \\
290 \\
554 \\
1,266 \\
1,792 \\
1,142 \\
524 \\
212 \\
98 \\
47 \\
1\end{array}$ & $\begin{array}{r}0 \cdot 08 \\
0 \cdot 05 \\
0 \cdot 11 \\
0 \cdot 36 \\
0 \cdot 22 \\
0 \cdot 54 \\
0 \cdot 69 \\
1 \cdot 56 \\
3 \cdot 01 \\
4 \cdot 57 \\
8 \cdot 73 \\
19 \cdot 95 \\
28 \cdot 24 \\
18 \cdot 00 \\
8 \cdot 26 \\
3 \cdot 34 \\
1 \cdot 54 \\
0.74 \\
0.02\end{array}$ & $\begin{array}{r}8 \\
10 \\
11 \\
14 \\
21 \\
30 \\
43 \\
125 \\
178 \\
332 \\
651 \\
1,487 \\
2,034 \\
1,335 \\
660 \\
188 \\
91 \\
47 \\
4\end{array}$ & $\begin{array}{r}0.11 \\
0.14 \\
0.15 \\
0.19 \\
0.29 \\
0.41 \\
0.59 \\
1 \cdot 72 \\
2.45 \\
4.57 \\
8.96 \\
20.46 \\
27.99 \\
18.37 \\
9.08 \\
2.59 \\
1.25 \\
0.65 \\
0.06\end{array}$ & $\begin{array}{r}3 \\
3 \\
5 \\
13 \\
8 \\
12 \\
24 \\
41 \\
66 \\
137 \\
273 \\
625 \\
937 \\
534 \\
230 \\
94 \\
39 \\
18 \\
\end{array}$ & $\begin{array}{c}0 \cdot 10 \\
0 \cdot 10 \\
0 \cdot 16 \\
0.42 \\
0.26 \\
0.39 \\
0.78 \\
1 \cdot 34 \\
2 \cdot 16 \\
4 \cdot 47 \\
8 \cdot 91 \\
20 \cdot 41 \\
30.60 \\
17 \cdot 44 \\
7 \cdot 51 \\
3.07 \\
1 \cdot 27 \\
0.59 \\
-\end{array}$ \\
\hline $\begin{array}{l}\text { Number of Births } \\
\text { Mean (days) } \\
\text { Error of Mean } \\
\text { Standard Deviation }\end{array}$ & $\begin{array}{l}\cdots \\
\cdots \\
\cdots \\
\cdots\end{array}$ & $\begin{array}{r}6,346 \\
280 \cdot 76 \\
0 \cdot 18 \\
14 \cdot 36\end{array}$ & ${ }^{100}=$ & $\begin{array}{r}7,269 \\
280 \cdot 73 \\
0 \cdot 17 \\
14 \cdot 14\end{array}$ & ${ }^{100}-$ & $\begin{array}{r}3,062 \\
280 \cdot 58 \\
0 \cdot 25 \\
14 \cdot 05\end{array}$ & ${ }^{100}$ - \\
\hline
\end{tabular}

Ward group was unknown in 72 of the 16,749 births referred to in Table III, Part II.

TABLE V

Birth Weight related to Duration of Gestation

\begin{tabular}{|c|c|c|c|c|c|c|}
\hline \multirow{3}{*}{$\begin{array}{l}\text { Duration of Gestation } \\
\text { (weeks) }\end{array}$} & \multicolumn{6}{|c|}{ Ward Group } \\
\hline & \multicolumn{2}{|c|}{ I } & \multicolumn{2}{|c|}{ II } & \multicolumn{2}{|c|}{ III } \\
\hline & $\begin{array}{l}\text { Number } \\
\text { of Births }\end{array}$ & $\begin{array}{c}\text { Mean } \\
\text { Weight } \\
\text { (lb.) }\end{array}$ & $\begin{array}{l}\text { Number } \\
\text { of Births }\end{array}$ & $\begin{array}{c}\text { Mean } \\
\text { Weight } \\
\text { (lb.) }\end{array}$ & $\begin{array}{l}\text { Number } \\
\text { of Births }\end{array}$ & $\begin{array}{l}\text { Mean } \\
\text { Weight } \\
\text { (lb.) }\end{array}$ \\
\hline $\begin{array}{l}28- \\
30- \\
32- \\
34- \\
36- \\
38- \\
40- \\
42- \\
44-\end{array}$ & $\begin{array}{r}8 \\
30 \\
48 \\
143 \\
481 \\
1,820 \\
2,934 \\
736 \\
146\end{array}$ & $\begin{array}{l}2 \cdot 00 \\
3 \cdot 07 \\
3 \cdot 79 \\
5 \cdot 34 \\
6 \cdot 25 \\
6 \cdot 74 \\
7 \cdot 22 \\
7 \cdot 31 \\
7 \cdot 34\end{array}$ & $\begin{array}{r}18 \\
25 \\
51 \\
168 \\
510 \\
2,138 \\
3,369 \\
848 \\
142\end{array}$ & $\begin{array}{l}2 \cdot 33 \\
2 \cdot 96 \\
3 \cdot 65 \\
5 \cdot 37 \\
6 \cdot 18 \\
6 \cdot 88 \\
7 \cdot 23 \\
7 \cdot 39 \\
7 \cdot 39\end{array}$ & $\begin{array}{r}6 \\
18 \\
20 \\
65 \\
203 \\
898 \\
1,471 \\
324 \\
57\end{array}$ & $\begin{array}{l}2 \cdot 33 \\
2 \cdot 83 \\
3 \cdot 65 \\
5 \cdot 49 \\
6 \cdot 18 \\
6 \cdot 86 \\
7 \cdot 19 \\
7 \cdot 25 \\
7 \cdot 38\end{array}$ \\
\hline Total & 6,346 & - & 7,269 & - & 3,062 & - \\
\hline
\end{tabular}


SUMMARY

The standard of housing has been used as a basis of classification of Birmingham city wards into three groups, to which single births for the year 1947 have been allocated by place of domicile. It is shown that birth weight is slightly but significantly lower in the poorest group than in the other two groups. This difference is not accounted for by differences in the birth rank of births in each group, and is greater when first births are compared. There are no differences in duration of gestation, as measured by the mean and percentage distribution.

\section{REFERENCES}

Baird, D. (1945). J. Obstet. Gynaec. Brit. Emp., 52, 217.

Douglas, J. W. B. (1950). Ibid., 57, 143.

Record, R. G., and McKeown, T. (1949). British Journal of Social Medicine, 3, 183. 